SCIENTIFIC LETTER

\title{
Low grade inflammation is notably suppressed by conventional anti-inflammatory treatment: a randomised crossover trial
}

\author{
C G Perry, S J Cleland, J M Connell, J R Petrie, N Sattar
}

Heart 2004;90:804-805. doi: 10.1136/hrt.2003.022129

$C^{i}$ irculating concentrations of $\mathrm{C}$ reactive protein (CRP), a hepatic derived inflammatory marker that is secreted in response to specific cytokines, have been shown to predict the risk of coronary heart disease (CHD) and diabetes in large epidemiological studies. ${ }^{12}$ These data highlight the concept that inflammation is a central component of the pathogenesis of atherosclerosis. The plaque composition of unstable coronary lesions includes an abundance of inflammatory molecules and cells at the shoulder region and these may act to erode the collagen cap separating the atheromatous material of the plaque from blood. The strength of the prospective data linking CRP to CHD are such that a recent American Heart Association/Centers for Disease Control and Prevention consensus report suggested that high sensitivity CRP assays may be employed in helping predict CHD risk. ${ }^{1}$

The recognition of the contribution of inflammation to atherosclerosis has focused attention on the impact of treatments on inflammatory markers. Treatments with proven effects on cardiovascular mortality, such as the lipid lowering 3-hydroxy-3-methylglutaryl coenzyme A (HMG-Co A) reductase inhibitors (statins) and also the insulin sensitising peroxisome proliferator activated receptor $\gamma$ activators (thiazolidinediones), exhibit anti-inflammatory effects providing indirect support for the inflammation hypothesis. ${ }^{1}$ For example, recent trials suggest a CRP reduction of $15-40 \%$ with statins. ${ }^{134}$ Detailed molecular mechanisms for such effects are emerging. However, the impact of other conventional anti-inflammatory treatments on highly sensitive markers of inflammation such as CRP has been sparsely studied. Such information is potentially important since there is wide interest in the development of novel therapeutic approaches in cardiovascular and metabolic disease. Accordingly, we have assessed the impact of glucocorticoid administration on circulating concentrations of CRP in healthy male subjects.

\section{METHODS}

We conducted a double blind, randomised placebo controlled, crossover trial of five days of $1 \mathrm{mg}$ twice daily dexamethasone treatment or matched placebo in young healthy men. The two phases were separated by a four week washout period, with blood and urine samples collected at the end of each phase. CRP was measured using a sensitive double antibody sandwich enzyme linked immunosorbent assay (ELISA) with rabbit anti-human CRP and peroxidase conjugated rabbit anti-human CRP. The assay had a lower sensitivity of $0.10 \mathrm{mg} / \mathrm{l}$ and was linear up to $5 \mathrm{mg} / \mathrm{l}$ and logarithmic thereafter. The inter-assay CV (coefficient of variation) was less than $6 \%$. Change in urinary-free cortisol (UFC) and CRP concentrations were compared by paired Wilcoxon test.

\section{RESULTS}

Nineteen male volunteers completed both phases of the study. None reported any serious illness or infection before the study; one had a basal CRP $>10 \mathrm{mg} / \mathrm{l}$, indicative of a subclinical infection. This subject's data were therefore excluded from further analyses. The mean age of the volunteers was 24 years, mean body mass index (BMI) was $24 \mathrm{~kg} / \mathrm{m}^{2}$, and median blood pressure was 129/66 mm Hg.

Following five days of dexamethasone $1 \mathrm{mg}$ twice daily, UFC declined from 6.76 to $0.31 \mu \mathrm{mol} / \mathrm{mol}$ creatine $(\mathrm{p}<0.0001)$. There was no change in BMI during the study. Circulating CRP concentrations declined significantly; median CRP concentration after placebo was $0.83 \mathrm{mg} / \mathrm{l}$ (interquartile range (IQR) $0.13-1.75 \mathrm{mg} / \mathrm{l}$ ), whereas median CRP concentration after dexamethasone was $0.15 \mathrm{mg} / \mathrm{l}$ (IQR $0.11-0.53 \mathrm{mg} / \mathrm{l})(\mathrm{p}=0.001$, Wilcoxon test $)$. This reduction represents an $82 \%$ decline in median CRP concentration; 17 of 18 men achieved a CRP concentration of $<1 \mathrm{mg} / \mathrm{l}$.

The extent of reduction correlated to baseline CRP concentration $(r=0.80, \mathrm{p}<0.001)$. Thus, the median CRP concentration fell by $80 \%$ in the six men with the highest basal CRP concentrations (median $2.27 \mathrm{mg} / \mathrm{l}$ ), 63\% in those with intermediate basal concentrations (median $0.74 \mathrm{mg} / \mathrm{l}$ ), but did not change in those with the lowest basal concentrations $(0.12 \mathrm{mg} / \mathrm{l})($ table 1$)$. Clearly, the sensitivity of the assay precluded definitive results for the latter group.

\section{DISCUSSION}

Using a robust study design, we demonstrated that modestly elevated CRP concentrations in the context of low grade inflammation are notably suppressed following five days of dexamethasone treatment. The extent of reduction in the group as a whole was approximately $80 \%$, considerably greater than that reported with statin treatment. ${ }^{1}$ Moreover, CRP reduction was particularly pronounced in those with high basal concentrations and predictably negligible in those with low basal values.

The mechanism of CRP reduction with corticosteroids is not clear but is presumably a consequence of the same molecular mechanisms that subserve the more commonly recognised anti-inflammatory actions of glucocorticoids. Inhibition of NFKB may be central in this regard. While there is no suggestion that glucocorticoid reduction of CRP has potential as an anti-atherogenic treatment, these results are of interest on at least two grounds. Firstly, they reveal for the first time the extent to which low grade inflammatory

Abbreviations: $\mathrm{BMI}$, body mass index; $\mathrm{CHD}$, coronary heart disease $C R P, C$ reactive protein; $I Q R$, interquartile range; UFC, urinary-free cortisol 
Table 1 Median CRP concentrations after placebo and dexamethasone treatment in all subjects and in subjects grouped according to baseline CRP concentration

\begin{tabular}{|c|c|c|c|c|c|}
\hline & $\begin{array}{l}\text { CRP concentration } \\
\text { following placebo (mg/l) }\end{array}$ & $\begin{array}{l}\text { CRP concentration following } \\
\text { dexamethasone (mg/l) }\end{array}$ & $\begin{array}{l}\text { \% Change in CRP } \\
\text { concentration }\end{array}$ & $\begin{array}{l}95 \% \mathrm{Cl} \text { for change in CRP } \\
\text { concentration (mg/l) }\end{array}$ & p Value \\
\hline $\begin{array}{l}\text { All subjects }(n=18) \\
\text { By basal CRP }\end{array}$ & 0.83 & 0.16 & $-80 \%$ & -0.18 to -1.37 & 0.001 \\
\hline High $(n=6)$ & 2.27 & 0.45 & $-80 \%$ & -1.13 to -4.20 & 0.036 \\
\hline Medium $(n=6)$ & 0.74 & 0.27 & $-63 \%$ & -0.170 to -0.77 & 0.036 \\
\hline Low $(n=6)$ & 0.12 & 0.12 & $0 \%$ & -0.045 to 0.055 & NS \\
\hline
\end{tabular}

responses can be suppressed and indicate that elevated CRP concentrations, in apparently healthy individuals, may indeed reflect chronic cytokine leakage. Secondly, they provide a benchmark against which to compare the CRP lowering effects of existing cardioprotective agents such as statins and, in the future, a comparison for newer classes of statins designed as anti-inflammatory agents rather than lipid lowering agents. ${ }^{3}$ As indicated earlier, currently available statins can only modestly reduce CRP concentrations.

These results may not be applicable to patients with CHD; nevertheless, it is perhaps relevant to note the recent finding that oral prednisone treatment resulted in a striking reduction of clinical events and angiographic stenosis rate in patients with persistently high CRP concentrations $(>5 \mathrm{mg} / \mathrm{l})$ after successful coronary artery stent implantation. ${ }^{5}$

In conclusion, while the question of whether CRP is directly atherogenic remains controversial, there is evidence that it may cause endothelial activation and hypercoagulation. ${ }^{1}$ Based on a wealth of prospective data, an ideal CRP concentration of $<1 \mathrm{mg} / \mathrm{l}$ has recently been proposed; concentrations above $3 \mathrm{mg} / \mathrm{l}$ are considered high, and such individuals have a more than twofold risk of CHD after adjusting for conventional risk factors. ${ }^{1}$ Our study clearly illustrates that conventional anti-inflammatory treatment can dampen CRP to $<1 \mathrm{mg} / \mathrm{l}$ in the vast majority of cases.

\section{Authors' affiliations}

C G Perry, S J Cleland, J M Connell, J R Petrie, Department of Cardiovascular and Medical Sciences, University of Glasgow, Glasgow, UK

N Sattar, Department of Pathological Biochemistry and Medicine, University of Glasgow

Correspondence to: Dr Naveed Sattar, Department of Pathological Biochemistry and Medicine, Glasgow Royal Infirmary University NHS Trust, Glasgow G31 2ER, UK; nsattar@clinmed.gla.ac.uk

\section{Accepted 27 October 2003}

\section{REFERENCES}

1 Pearson TA, Mensah GA, Alexander RW, et al. Markers of inflammation and cardiovascular disease: application to clinical and public health practice: a statement for healthcare professionals from the Centers for Disease Control and Prevention and the American Heart Association. Circulation 2003:107:499-511.

2 Sattar N, Perry CG, Petrie JR. Type 2 diabetes as an inflammatory disorder. Br J Diabetes Vascular Dis 2003;3:36-41.

3 Jialal I, Stein D, Balis D, et al. S. Effect of hydroxymethyl glutaryl coenzyme a reductase inhibitor therapy on high sensitive $C$-reactive protein levels. Circulation 2001;103:1933-5.

4 van de Ree MA, Huisman MV, Princen HM, et al. Strong decrease of high sensitivity $\mathrm{C}$-reactive protein with high-dose atorvastatin in patients with type 2 diabetes mellitus. Atherosclerosis 2003;166:129-35.

5 Versaci F, Gaspardone A, Tomai F, et al. Immunosuppressive Therapy for the Prevention of Restenosis after Coronary Artery Stent Implantation Study. Immunosuppressive Therapy for the Prevention of Restenosis after Coronary Artery Stent Implantation (IMPRESS Study). J Am Coll Cardiol 2002;40:1935-42.
WEB TOP 10

www.heartinl.com

These articles scored the most hits on Heart's website during April 2004

1 The pathophysiology of myocardial ischaemia

DC Crossman

May 2004;90:576-80. (Education in Heart)

2 Assessing the risk of sudden cardiac death in a patient with hypertrophic cardiomyopathy

M P Frenneaux

May 2004;90:570-5. (Education in Heart)

3 Pregnancy in heart disease

SA Thorne

April 2004;90:450-6. (Education in Heart)

4 Adjunctive treatment in patients treated with thrombolytic therapy

MA Brouwer, N Clappers, FWA Verheugt

March 2004;90:581-8. (Education in Heart)

5 Angina pectoris and normal coronary arteries: cardiac syndrome $X$

F Crea, GA Lanza

April 2004;90:457-63. (Education in Heart)

6 Beyond the measurement of QRS complex toward mechanical dyssynchrony: cardiac resynchronisation therapy in heart failure patients with a normal QRS duration A Auricchio, CM Yu

May 2004;90:479-81. (Editorial)

7 Cardiac effects of anabolic steroids

JR Payne, PJ Kotwinski, HE Montgomery

May 2004;90:473-5. (Editorial)

8 Poor concordance of commonly used echocardiographic measures of left ventricular diastolic function in patients with suspected heart failure but preserved systolic function: is there a reliable echocardiographic measure of diastolic dysfunction?

MC Petrie, K Hogg, L Caruana, JJV McMurray

May 2004;90: 511-17. (Cardiovascular medicine)

9 Inflammatory mediators in chronic heart failure: an overview

SD Anker, $S$ von Haehling

April 2004;90:464-70. (Education in Heart)

$10 \mathrm{C}$ Reactive protein, moderate alcohol consumption, and long term prognosis after successful coronary stenting: four year results from the GENERATION study

MN Zairis, JA Ambrose, AG Lyras, MA Thoma, PK Psarogianni, PG Psaltiras, AD Kardoulas, GP Bibis, EG Pissimissis, PC Batika, MC DeVoe, AA Prekates, SG Foussas April 2004;90:419-24. (Interventional cardiology and surgery) Visit the Heart website for hyperlinks to these articles, by clicking on "Top 10 papers" www.heartinl.com 